\title{
Characterization of inhibitory supernatants produced by bacteria isolated from goat
}

\section{milk}

Caracterização de sobrenadantes inibitórios produzidlos por bactérias isoladas de leite de cabra

Caracterización de sobrenadantes inhidores producidos por bactérias aisladas de la leche de cabra

Received: 12/31/2021 | Reviewed: 01/05/2022 | Accept: 01/15/2022 | Published: 01/17/2022

Liliane Andrade da Silva

ORCID: https://orcid.org/0000-0002-4623-0974

Federal University of Paraíba, Brazil

E-mail: liliane andrade1984@hotmail.com

Annie Evelyn Souto Raposo

ORCID: https://orcid.org/0000-0002-3868-575X

Federal University of Paraíba, Brazil

E-mail: aevelynsr@hotmail.com

José Honório Pereira Lopes Neto

ORCID: https://orcid.org/0000-0002-0002-8324

Federal University of Paraíba, Brazil

E-mail: netoea22@gmail.com

Kléber de Sousa Oliveira

ORCID: https://orcid.org/0000-0003-4697-7207

Catholic University of Brasília, Brazil

E-mail: klbrdesousa@gmail.com

Evandro Leite Souza

ORCID: https://orcid.org/0000-0003-4927-9383

Federal University of Paraíba, Brazil

E-mail: evandroleitesouza@hotmail.com

Octávio Luiz Franco

ORCID: https://orcid.org/0000-0001-9546-0525

Catholic University of Brasília, Brazil E-mail: ocfranco@gmail.com

Haíssa Roberta Cardarelli

ORCID: https://orcid.org/0000-0002-8087-3017

Federal University of Paraíba, Brazil

E-mail: hrcarda@gmail.com

\begin{abstract}
Several compounds can be produced by lactic acid bacteria (LAB) isolated from milk such as bacteriocins, small cationic and thermostable peptides, that possess antimicrobial activity. The technological application of these antimicrobial compounds became important for the industry mainly because of chemical preservatives. This study aimed to isolate LAB with anti-Listeria monocytogenes activity from raw goat milk and to characterize their inhibitory cell-free supernatants (CFS). It was performed Isolation of LAB from raw goat milk, inhibitory activity of the CFS, characterization of CFS inhibitory activity under different conditions, mode of action of the active CFS, adsorption of the anti-Listeria substances present in the CFS of LS2 to L. monocytogenes, molecular identification of LAB isolates with anti-Listeria activity. Three isolated strains produced CFS with active inhibitory substances of proteinaceous nature, identified by $16 \mathrm{~S}$ rDNA as Weissella cibaria (LS1) and Lactococcus lactis (LS2 and LS3). The CFS of LS2 showed the highest anti-Listeria activity (1600 arbitrary units $/ \mathrm{mL})$ after $2 \mathrm{~h}$ at $\mathrm{pH} 6.0$ and was bacteriostatic and active at low $\mathrm{pH}$ at temperatures of $4{ }^{\circ} \mathrm{C}$ to $80{ }^{\circ} \mathrm{C}$. The results suggest that the LS2 strain is a biopreservative culture with potential for applications to control L. monocytogenes in foods.
\end{abstract}

Keywords: Raw goat milk; Lactic acid bacteria; Antimicrobial peptide; Biopreservation.

\section{Resumo}

Vários compostos podem ser produzidos por bactérias lácticas (BAL) isoladas do leite, como as bacteriocinas, pequenos peptídeos catiônicos e termoestáveis, que possuem atividade antimicrobiana. A aplicação tecnológica desses compostos antimicrobianos tornou-se importante para a indústria principalmente por causa dos conservantes químicos. Este estudo teve como objetivo isolar LAB com atividade anti-Listeria monocytogenes de leite de cabra cru e caracterizar seus sobrenadantes livres de células inibitórios (CFS). Foi realizado isolamento do LAB do leite de cabra cru, atividade inibitória do CFS, caracterização da atividade inibitória do CFS sob diferentes condições, modo de ação do CFS ativo, adsorção das substâncias anti-Listeria presentes no SFC de LS2 a L. monocytogenes, identificação molecular de isolados de LAB com atividade anti-Listeria. Três cepas isoladas produziram CFS com substâncias inibidoras ativas de natureza 
proteica, identificadas pelo rDNA 16s como Weissella cibaria (LS1) e Lactococcus lactis (LS2 e LS3). O CFS de LS2 apresentou a maior atividade anti-Listeria (1600 unidades arbitrárias/ ml) após $2 \mathrm{~h}$ em pH 6,0 e foi bacteriostático e ativo em baixo $\mathrm{pH}$ em temperaturas de $4{ }^{\circ} \mathrm{C}$ a $80{ }^{\circ} \mathrm{C}$. Os resultados sugerem que a cepa LS2 é uma cultura biopreservativa com potencial para aplicações no controle de L. monocytogenes em alimentos.

Palavras-chave: Leite de cabra cru; Bactéria ácido lática; Peptídeo antimicrobiano; Biopreservação.

\section{Resumen}

Las bacterias del ácido láctico (LAB) aisladas de la leche pueden producir varios compuestos, como las bacteriocinas, pequeños péptidos catiónicos y termoestables, que tienen actividad antimicrobiana. La aplicación tecnológica de estos compuestos antimicrobianos se ha vuelto importante para la industria principalmente debido a los conservantes químicos. Este estudio tuvo como objetivo aislar LAB con actividad anti-Listeria monocytogenes de leche cruda de cabra y caracterizar sus sobrenadantes inhibidores libres de células (CFS). Aislamiento de LAB a partir de leche cruda de cabra, actividad inhibidora del CFS, caracterización de la actividad inhibidora del CFS en diferentes condiciones, modo de acción del CFS activo, adsorción de sustancias anti-Listeria presentes en el CFS de LS2 a L. monocytogenes, se realizó la identificación de aislados de LAB con actividad anti-Listeria. Tres cepas aisladas produjeron CFS con sustancias inhibidoras activas de naturaleza proteica, identificadas por rDNA 16s como Weissella cibaria (LS1) y Lactococcus lactis (LS2 y LS3). LS2 CFS tuvo la mayor actividad anti-Listeria (1600 unidades arbitrarias/ ml) después de 2 ha pH 6.0 y fue bacteriostático y activo a pH bajo a temperaturas de $4{ }^{\circ} \mathrm{C}$ a $80{ }^{\circ} \mathrm{C}$. Los resultados sugieren que la cepa LS2 es un cultivo bioconservante con potencial para aplicaciones en el control de L. monocytogenes en alimentos. Palabras clave: Leche cruda de cabra; Bacterias de ácido láctico; Péptido antimicrobiano; Biopreservación.

\section{Introduction}

Goat milk is a complete food, composed of proteins, essential fatty acids, minerals, and vitamins (Queiroga et al., 2016). Lactic acid bacteria (LAB) naturally found in goat milk can produce several compounds with activity against other bacteria, including bacteriocins (Furtado et al., 2015). The raw goat milk microbiota is considered a good source of novel bacteriocinogenic strains that can be exploited as an alternative for use as biopreservatives in foods (Perin and Nero 2014).

Bacteriocins are generally small cationic and thermostable peptides that possess antimicrobial activity. These molecules show variations regarding their molecular masses, biochemical properties, spectrum of antibacterial activity, and mechanism of action (Biscola et al., 2013; Furtado et al., 2015; Umu et al., 2016). Bacteriocins produced by LAB can inhibit growth and survival of pathogenic and spoilage microorganisms in foods. Assayed in food-based systems, bacteriocins from LAB inhibit Bacillus cereus, Staphylococcus aureus, Clostridium tyrobutyricum, Pseudomonas aeruginosa and L. monocytogenes (Bizani et al., 2008; Furtado et al., 2015; Malheiros; Cuccovia and Franco, 2016; Barman; Ghosh and Mandal, 2018; Kaktcham et al., 2019).

The Listeria genus is widely distributed in nature, and the L. monocytogenes species has great importance to the food industry, due to the occurrence of listeriosis after the intake of foods contaminated with cells of this bacterium. Listeriosis is recognized as a serious public health hazard with high mortality rates in susceptible individuals (Swaminathan and Gerner-Smidt, 2007). L. monocytogenes can survive at low temperatures and has the ability to form biofilms in processing plants, especially affecting the dairy industry. This bacterium is usually found in dairy products including cheese (Coelho et al., 2014).

Some peptides with activity against L. monocytogenes produced by LAB strains such as nisin A, nisin Z and lacticin, have been identified recently (Dal Bello et al., 2012). The technological application of these antimicrobial compounds is of interest for the industry because there is an increasing concern over the use of chemical preservatives; thus, new bacteriocinogenic LAB strains and their bacteriocins are continuously being searched for. However, studies regarding the identification and characterization of new LAB strain producers of anti-Listeria peptides are still scarce, particularly involving LAB isolated from raw goat milk.

The study of bacteriocin production by LABs, particularly those that are active against L. monocytogenes, is necessary to evaluate their technological application as natural preservatives in foods frequently contaminated with this bacterium, such as dairy products (Cavicchioli; Dornellas and Perin, 2015; Dal Bello et al., 2012). However, important issues, such as maintenance 
of activity in a range of $\mathrm{pH}$ values, high temperature or high salt concentration, as well as continued activity in the presence of some chemical additives, must be considered for the use of bacteriocins in the preservation of food products (Biscola et al. 2013). Considering these aspects, the aim of this study was to isolate and identify LAB from raw goat milk with activity against $L$. monocytogenes, as well as to partially characterize the active cell-free supernatants to evaluate their potential for application as anti-Listeria biopreservatives in food matrices.

\section{Material and Methods}

\subsection{Sample collection and bacterial strains}

Samples of raw goat milk were directly obtained from producers on small farms in Cariri (semi-arid region), Paraíba, Brazil, after manual milking under sterile conditions. Samples were transported under refrigeration (4- $\left.7^{\circ} \mathrm{C}\right)$ and processed within $24 \mathrm{~h}$ for the isolation of lactic acid bacteria with possible anti-Listeria activity. The bacterial strains used as indicators to determine the inhibitory activity of the cell-free supernatants (CFS) were obtained from commercial sources, the Collection of Microorganisms from the Laboratory of Food Microbiology, Department of Food and Experimental Nutrition, Faculty of Pharmaceutical Sciences, University of São Paulo, Brazil (USP) and the Collection of Microorganisms from the Laboratory of Food Microbiology, Department of Nutrition, Federal University of Paraíba (UFPB) (Table 1).

Table 1 - Indicator microorganisms and incubation conditions used for inhibitory activity assays of cell-free supernatants (CFS) of the isolated strains from raw goat milk.

\section{Microorganism}

Listeria monocytogenes Scott A (USP)

Listeria monocytogenes ATCC 7644

Listeria monocytogenes L506 (USP)

Listeria monocytogenes L620 (USP)

Listeria monocytogenes L302 (USP)

Listeria monocytogenes L211 (USP)

Listeria monocytogenes L409 (USP)

Listeria monocytogenes 711 (USP)

Enterococcus faecium ATCC 19433

Staphylococcus aureus ATCC 27664

Escherichia coli ATCC 29214

Salmonella spp 29 (UFPB)

Lactobacillus casei BGP $93 \dagger$

Bifidobacterium lactis $\mathrm{BLC} 1 \uparrow$

Bifidobacterium lactis $\mathrm{Bb} 12 \AA \uparrow$

Lactobacillus acidophilus LA3†

Lactobacillus acidophilus LA-5†

Lactobacillus delbruecki subsp. bulgaricus (YF L812) $\dagger$

Streptococcus termophilus (YF- L812)

Lactococcus lactis subsp. lactis and Lactococcus lactis subsp. cremoris (R-704)

\section{Incubation Conditions}

$\mathrm{BHI} / 37^{\circ} \mathrm{C}$

$\mathrm{BHI} / 37^{\circ} \mathrm{C}$

$\mathrm{BHI} / 37^{\circ} \mathrm{C}$

$\mathrm{BHI} / 37^{\circ} \mathrm{C}$

$\mathrm{BHI} / 37^{\circ} \mathrm{C}$

$\mathrm{BHI} / 37^{\circ} \mathrm{C}$

$\mathrm{BHI} / 37^{\circ} \mathrm{C}$

$\mathrm{BHI} / 37^{\circ} \mathrm{C}$

$\mathrm{BHI} / 37^{\circ} \mathrm{C}$

$\mathrm{BHI} / 37^{\circ} \mathrm{C}$

$\mathrm{BHI} / 37^{\circ} \mathrm{C}$

$\mathrm{BHI} / 37^{\circ} \mathrm{C}$

$\mathrm{MRS} / 30^{\circ} \mathrm{C}$

$\mathrm{MRS} / 30^{\circ} \mathrm{C}$

$\mathrm{MRS} / 30^{\circ} \mathrm{C}$

$\mathrm{MRS} / 30^{\circ} \mathrm{C}$

$\mathrm{MRS} / 30^{\circ} \mathrm{C}$

$\mathrm{MRS} / 30^{\circ} \mathrm{C}$

$\mathrm{MRS} / 37^{\circ} \mathrm{C}$

$\mathrm{MRS} / 30^{\circ} \mathrm{C}$ 


\subsection{Isolation of LAB from raw goat milk}

The isolation of LAB from raw goat milk was performed according to Moraes et al. (2010) with modifications. Briefly, aliquots of $10 \mathrm{~mL}$ of goat milk were added to $90 \mathrm{~mL}$ of $1 \mathrm{~g} / \mathrm{L}$ peptone water. Serial dilutions $\left(10^{-1}\right.$ to $\left.10^{-8}\right)$ were prepared and inoculated on the surface $(0.1 \mathrm{~mL})$ or by pour plating $(1 \mathrm{~mL})$ in MRS agar (Himedia, Mumbai, Maharashtra, India) and incubated at $30^{\circ} \mathrm{C}$ or $37{ }^{\circ} \mathrm{C}$ for $48-72 \mathrm{~h}$ under aerobic conditions and anaerobically at $25^{\circ} \mathrm{C}, 30^{\circ} \mathrm{C}$ or $35-37{ }^{\circ} \mathrm{C}$ for $48-72 \mathrm{~h}$. A total of 60 colonies (five colonies per plate) with different morphologies and colors were picked from plates presenting 50 colonies maximum.

The selected colonies were re-cultivated in MRS broth (Himedia, Mumbai, Maharashtra, India) and spread-plated onto MRS agar under the same time-temperature conditions as in the isolation step. The pure cultures were Gram stained and catalaseproduction tested before storage at $-20{ }^{\circ} \mathrm{C}$ in $30 \%$ glycerol in MRS broth.

\subsection{Inhibitory activity of the cell-free supernatants (CFS)}

To verify the inhibitory spectrum of action of the CFS, 19 isolates classified as LAB were tested for inhibitory activity against the microorganisms listed in Table 1, according to procedures described by Rosa et al. (2002) with modifications. Aliquots of $10 \mu \mathrm{L}$ of CFS (pH 6.0) were sterilized by membrane filtration (Millex GV $0.22 \mu \mathrm{m}$, Merck Millipore, USA) and then spotted onto the surface of plates inoculated with $10^{5}$ to $10^{6} \mathrm{CFU} / \mathrm{mL}$ of each microorganism in selective medium, under ideal growth conditions and temperature for $24 \mathrm{~h}$.

\subsection{Characterization of CFS inhibitory activity under different conditions}

The filtered CFS obtained from the three LAB strains which presented anti-Listeria activity (LS1, LS2 and LS3) were adjusted to $\mathrm{pH}$ 6.0, subjected to sensitivity tests by treating with pepsin, Type II alpha-chymotrypsin from bovine pancreas, and protease type XIV from Streptomyces griseus (Sigma-Aldrich, St. Louis, Missouri, USA) at a concentration of $1.0 \mathrm{mg} / \mathrm{mL}$ and incubated at $37^{\circ} \mathrm{C}$ for $1 \mathrm{~h}$. Enzymatic inactivation was performed by heating to $97^{\circ} \mathrm{C}$ for $3 \mathrm{~min}$ (De Martinis and Franco, 1998).

The effect of $\mathrm{pH}$ and temperature on the anti-Listeria activity of the CFS was verified by adjusting the $\mathrm{pH}$ to 2.0,3.0, 4.0, 5.0, 6.0, 7.0, 8.0, 9.0, 10.0, and 11.0 (with $1 \mathrm{M} \mathrm{HCl}$ or $1 \mathrm{M} \mathrm{NaOH}$ ) and incubating at $25^{\circ} \mathrm{C}$ for $1 \mathrm{~h}$ and $2 \mathrm{~h}$, or by incubation of CFS (adjusted to $\mathrm{pH} 6.0$ ) at $4,25,30,37,45,60,80$, and $100^{\circ} \mathrm{C}$ for $1 \mathrm{~h}$ and $2 \mathrm{~h}$, and also at $121^{\circ} \mathrm{C}$ for $15 \mathrm{~min}$ (Albano et al., 2007). CFS were treated either with $10 \mathrm{~g} / \mathrm{L}$ Tween 20 or $10 \mathrm{~g} / \mathrm{L}$ Tween 80 (Synth, Sao Paulo, Brazil) and incubated for $2 \mathrm{~h}$ at $25^{\circ} \mathrm{C}$, or with $\mathrm{NaCl}\left(10,20,30,40\right.$ and $50 \mathrm{~g} / \mathrm{L}$ ) and incubated for $1 \mathrm{~h}$ at $7{ }^{\circ} \mathrm{C}$ (Todorov and Dicks, 2006). After the assays, CFS were adjusted to $\mathrm{pH} 6.0$ and subjected to the inhibitory activity test described previously using L. monocytogenes 711 as an indicator, for which a 1:128 dilution of the CFS was prepared and incubation was carried out at $37^{\circ} \mathrm{C}$ for $18-20 \mathrm{~h}$. Control assays were performed using the same conditions as in the tests, only with CFS.

\subsection{Mode of action of the active CFS}

Aliquots of $20 \mathrm{~mL}$ of anti-Listeria CFS were adjusted to $\mathrm{pH} 6.0$, membrane filtered, and added to $100 \mathrm{~mL}$ of $L$. monocytogenes 711 culture in early exponential phase ( $\mathrm{OD}_{600}$ of 0.1 to 0.2$)$. Optical density was measured every hour for $12 \mathrm{~h}$ of incubation at $37^{\circ} \mathrm{C}$ (Todorov and Dicks, 2006).

\subsection{Adsorption of the anti-Listeria substances present in the CFS of LS2 to L. monocytogenes}

The conditions tested employed different temperatures, $\mathrm{pH}$ levels, and chemicals to evaluate the adsorption of the bacteriocins present in the CFS of LS2 to L. monocytogenes 711. L. monocytogenes was incubated in BHI broth at $37{ }^{\circ} \mathrm{C}$ for 24 $\mathrm{h}$, centrifuged at $12,000 \times \mathrm{g}$ for $15 \mathrm{~min}$ at $4{ }^{\circ} \mathrm{C}$, washed twice with sterile saline solution $(8.5 \mathrm{~g} / \mathrm{L} \mathrm{NaCl})$, resuspended to $\mathrm{OD}_{600}$ 
of 0.1 to 0.2 , and $\mathrm{pH}$ adjusted $(4.0,6.0,8.0$ and 10.0). The suspension was mixed with an equal volume of CFS, incubated at $37{ }^{\circ} \mathrm{C}$ for $1 \mathrm{~h}$, centrifuged and subjected to the inhibitory activity test described previously. L. monocytogenes suspension (OD 0.1 to 0.2 , $\mathrm{pH} 6.5)$ was mixed with an equal volume of CFS, incubated at different temperatures $\left(4,25,30\right.$ and $\left.37{ }^{\circ} \mathrm{C}\right)$ for $1 \mathrm{~h}$, centrifuged and subjected to the inhibitory activity test described previously (Yildirim; Avsar and Yildirim, 2002). Another batch of L. monocytogenes cells was washed and resuspended, in this case with 5 mmol sterile phosphate buffer, treated with $10 \mathrm{~g} / \mathrm{L}$ Tween 80 or $10 \mathrm{~g} / \mathrm{L} \mathrm{NaCl}$, and then mixed with an equal volume of $\mathrm{CFS}$ and then incubated at $37{ }^{\circ} \mathrm{C}$ for $1 \mathrm{~h}$, centrifuged and subjected to the inhibitory activity test described previously (Albano et al., 2007).

\subsection{Molecular identification of LAB isolates with anti-Listeria activity}

The LS1, LS2 and LS3 isolates were subjected to 16S rRNA gene sequencing after DNA extraction using CTAB (hexadecyltrimethylammonium bromide, USB, Cleveland, Ohio, USA) according to procedures previously described by Oliveira et al (2006). PCR reactions were performed in an initial denaturation step of $3 \mathrm{~min}$ at $95{ }^{\circ} \mathrm{C}$, followed by 25 cycles of $30 \mathrm{~s}$ at $94{ }^{\circ} \mathrm{C}$ for denaturation, $30 \mathrm{~s}$ at $52{ }^{\circ} \mathrm{C}$ for hybridization of primers, and $1 \mathrm{~min} 40 \mathrm{~s}$ at $72{ }^{\circ} \mathrm{C}$ for extension, and subsequent final extension step at $72{ }^{\circ} \mathrm{C}$ for $7 \mathrm{~min}$. The amplified products were visualized in a $9 \mathrm{~g} / \mathrm{L}$ agarose gel. The primers used for amplification were 27F (5'-AGAGTTTGATCCTGGCTCAG-3') and 1492R (5'-GGTTACCTTGTTACGACTT-3') (Tuner et al. 1999). The amplification products were further purified (Pure Cycle kit EZNA, Georgia, USA) in mini-columns (Hibind DNA mini column, Georgia, USA) and sequenced in an automatic sequencer (Applied Biosystems 3130 xl Genetic Analyzer - Hitachi, Tokyo, Japan) using Big Dye Terminator v3.1 kit for Applied Biosystems (Life Technologies, Carlsbad, California, USA).

Sequences were analyzed using the BioEdit program (BioEdit Biological Sequence Alignment Editor, Carlsbad, California, USA) and compared to the gene sequences deposited in GenBank database (www.ncbi.nlm.gov/Genbank) and RBD (Ribosomal Database Project, East Lansing, Michigan, USA). The evolutionary history was inferred by using the maximum likelihood method based on the Tamura-Nei model. The tree with the highest log likelihood (-3853.2074) is shown. Initial tree(s) for the heuristic search were obtained automatically by applying the Neighbor-Joining and BioNJ algorithms to a matrix of pairwise distances estimated by using the maximum composite likelihood (MCL) approach, and then selecting the topology with the highest log likelihood value. The tree is drawn to scale, with branch lengths measured in the number of substitutions per site. The analysis involved eight nucleotide sequences. Codon positions included were $1 \mathrm{st}+2 \mathrm{nd}+3 \mathrm{rd}+$ noncoding. All positions containing gaps and missing data were eliminated. There were a total of 1340 positions in the final dataset. Evolutionary analyses were conducted in MEGA6 (Tamura et al., 2013).

\section{Results}

\subsection{LAB from raw goat milk and CFS activity}

A total of 19 Gram-positive and catalase-negative cultures were isolated from raw goat milk; CFS obtained from these isolates revealed no activity against the Gram-negative bacteria tested (Salmonella spp. and Escherichia coli ATCC 29214). CFS of three isolates (LS1, LS2 and LS3) presented activity against L. monocytogenes ATCC 7644 and L. monocytogenes 711, two isolated in anaerobic conditions (LS1 and LS3) and one isolated in aerobic conditions at $25^{\circ} \mathrm{C}$ (LS2). The activity levels against L. monocytogenes 711 observed for LS1, LS2 and LS3 were $400 \mathrm{AU} / \mathrm{mL}, 1600 \mathrm{AU} / \mathrm{mL}$ and $3200 \mathrm{AU} / \mathrm{mL}$, respectively.

\subsection{Characterization of CFS inhibitory activity under different conditions}

The anti-Listeria activity observed for CFS from LS1, LS2 and LS3 was not maintained after treatment with pepsin, type II alpha - chymotrypsin, and protease type XIV, suggesting that the active substances in the CFS are of a proteinaceous 
nature and further supporting the hypothesis of bacteriocin production. The effect of $\mathrm{pH}$ on the inhibitory activity of active CFS tested is presented in Figure 1.

Figure 1 - Effect of $\mathrm{pH}$ on the cell-free supernatants of LS1, LS2 and LS3 with anti-Listeria activity expressed in arbitrary units per $\mathrm{mL}(\mathrm{AU} / \mathrm{mL})$ (mean \pm standard deviation).

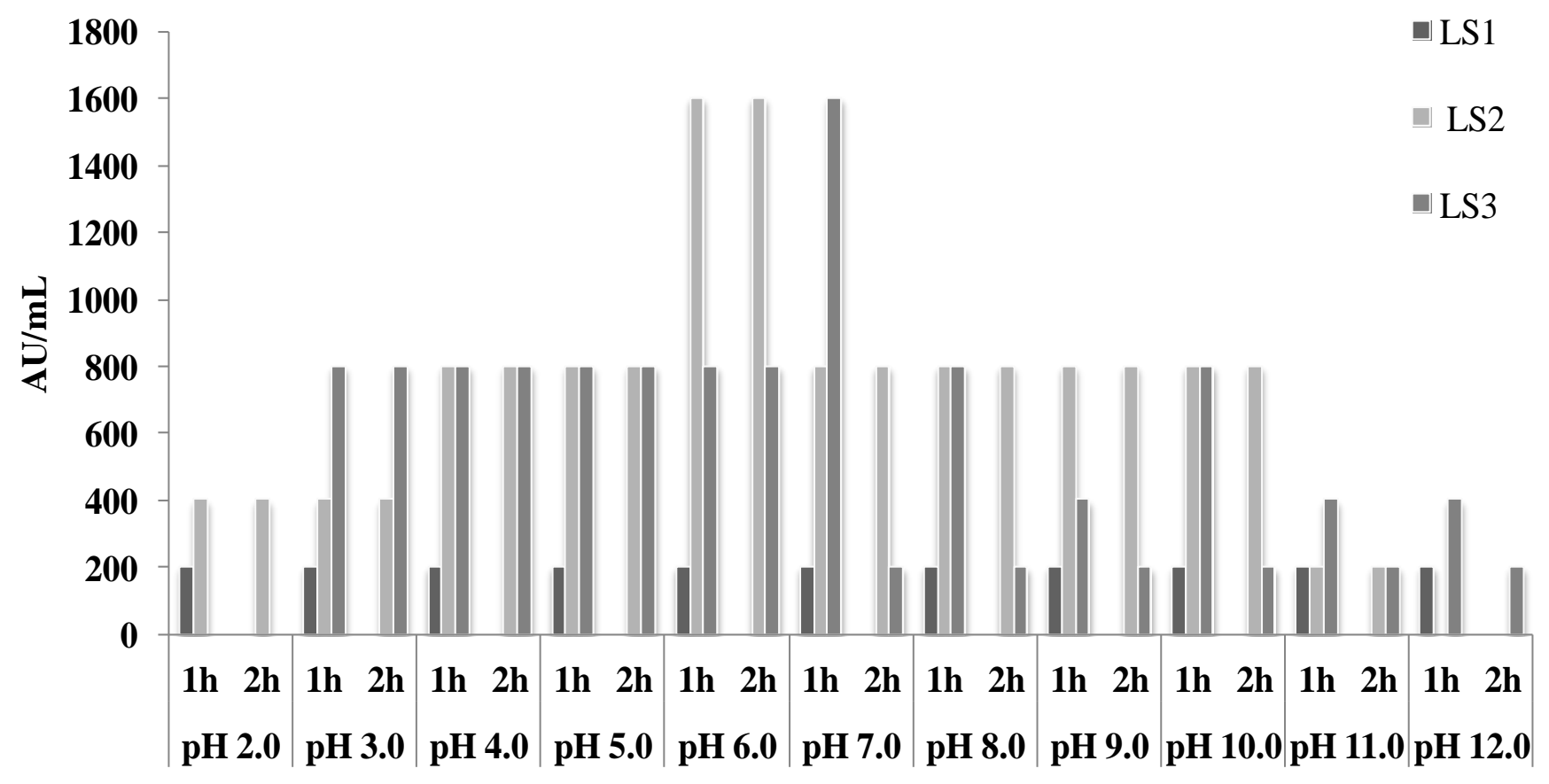

pH and incubation time ( $h$ )

Source: Authors.

The results showed that the CFS from LS1 lost activity after $2 \mathrm{~h}$ of treatment, with a higher sensitivity response to this parameter. The CFS from LS2 showed similar results to the CFS from LS3 at pH 4.0 and 5.0 with $1 \mathrm{~h}$ and $2 \mathrm{~h}$ of treatment, $\mathrm{pH}$ 10.0 with $1 \mathrm{~h}$ of treatment, and $\mathrm{pH} 11.0$ with $2 \mathrm{~h}$ of treatment, with activity of $800 \mathrm{AU} / \mathrm{mL}$; however, the best anti-Listeria activities were obtained from CFS from LS2 and LS3, with $2 \mathrm{~h}$ of treatment at $\mathrm{pH} 6.0$ and $1 \mathrm{~h}$ at $\mathrm{pH} 7.0$, respectively (1600 $\mathrm{AU} / \mathrm{mL}$ ). The resulting stability at $\mathrm{pH} 4.0-5.0$ is important in products with acidic $\mathrm{pH}$.

For the temperature assays, the activity of CFS from LS3 was more thermostable compared to LS1 and LS2 after $1 \mathrm{~h}$ of exposure to $4{ }^{\circ} \mathrm{C}, 25^{\circ} \mathrm{C}, 30{ }^{\circ} \mathrm{C}, 37^{\circ} \mathrm{C}, 45^{\circ} \mathrm{C}, 60{ }^{\circ} \mathrm{C}, 80{ }^{\circ} \mathrm{C}, 100{ }^{\circ} \mathrm{C}$ and after $15 \mathrm{~min}$ at $121{ }^{\circ} \mathrm{C}$ (Figure. 2). CFS from LS2 and LS3 maintained antimicrobial activities of $800 \mathrm{AU} / \mathrm{mL}$ and $1600 \mathrm{AU} / \mathrm{mL}$ respectively, in the temperature range from $4{ }^{\circ} \mathrm{C}$ to 80 ${ }^{\circ} \mathrm{C}$ after $1 \mathrm{~h}$ of exposure. On the other hand, CFS from LS1 presented low but stable activity of $200 \mathrm{AU} / \mathrm{mL}$ even after hot treatment in an autoclave for $15 \mathrm{~min}$. 
Figure. 2 - Effect of temperature on the cell-free supernatants of LS1, LS2 and LS3 with anti-Listeria activity (AU/mL) (mean \pm standard deviation).

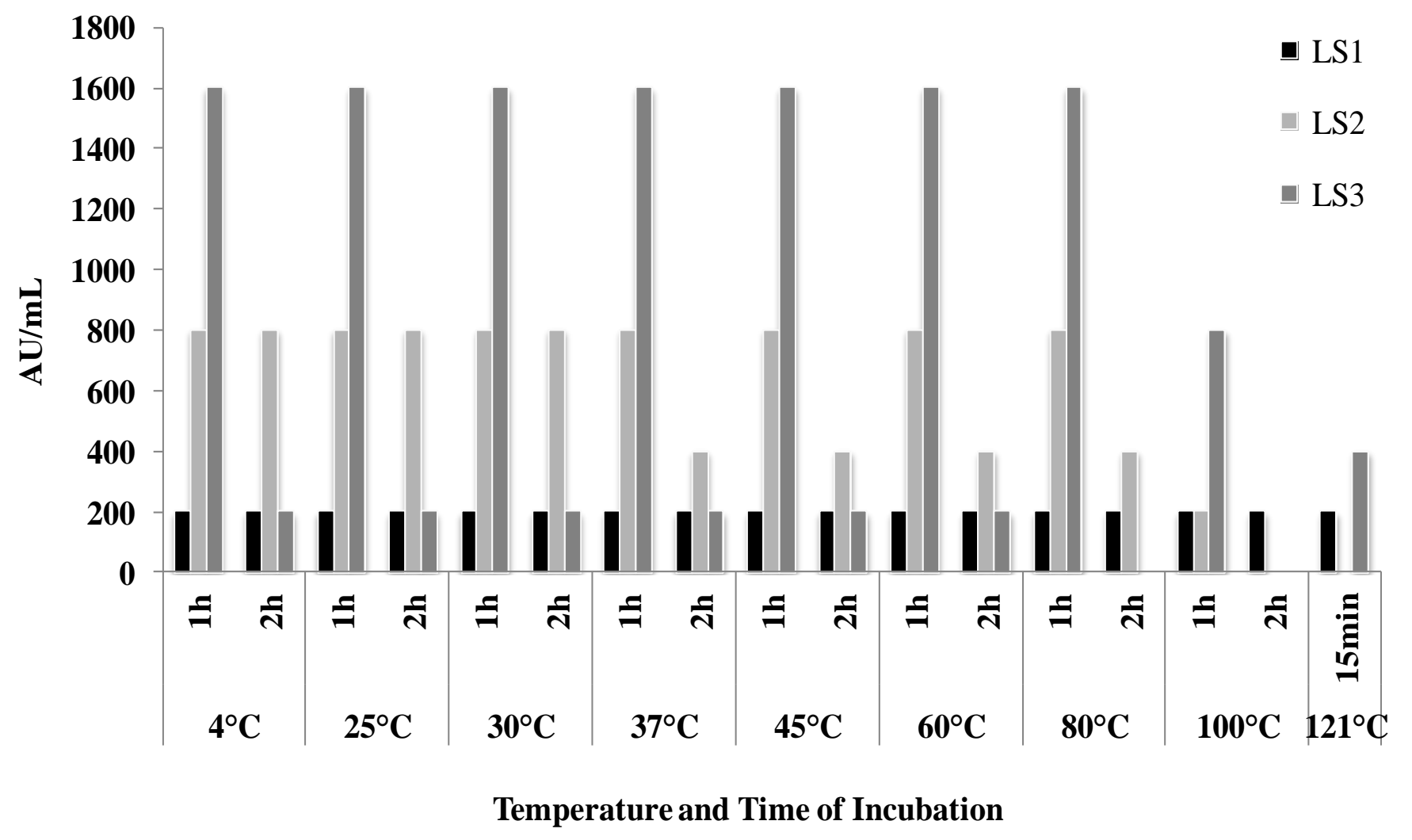

Source: Authors.

All CFS showed anti-Listeria activity of $200 \mathrm{AU} / \mathrm{mL}$ also after treatment with Tween 20 (10 g/L) and Tween 80 (10 $\mathrm{g} / \mathrm{L})$, as well as in all $\mathrm{NaCl}$ concentrations tested $(10,20,30,40$ and $50 \mathrm{~g} / \mathrm{L})$ at $7{ }^{\circ} \mathrm{C}$ for $1 \mathrm{~h}$. These results were probably due to the chemical structures of these compounds, suggesting that application of anti-Listeria active CFS in matrices with emulsifiers must be carefully evaluated. Additionally, the decrease of anti-Listeria activity in different $\mathrm{NaCl}$ concentrations indicates that the use of these substances to inhibit Listeria in salted foods should be avoided.

\subsection{Mode of action of the active CFS}

The CFS of LS2 was able to inhibit the growth of L. monocytogenes 711 for $5 \mathrm{~h}$, while CFS from LS1 and LS3 caused no inhibition because the $\mathrm{OD}_{600}$ of L. monocytogenes increased exponentially (Figure. 3). 
Figure 3 - Mode of action of the cell-free supernatants of (a) LS1, (b) LS2 and (c) LS3 with anti-Listeria activity on L. monocytogenes 711 growth measured by the optical density at $600 \mathrm{~nm}$ (mean \pm standard deviation).
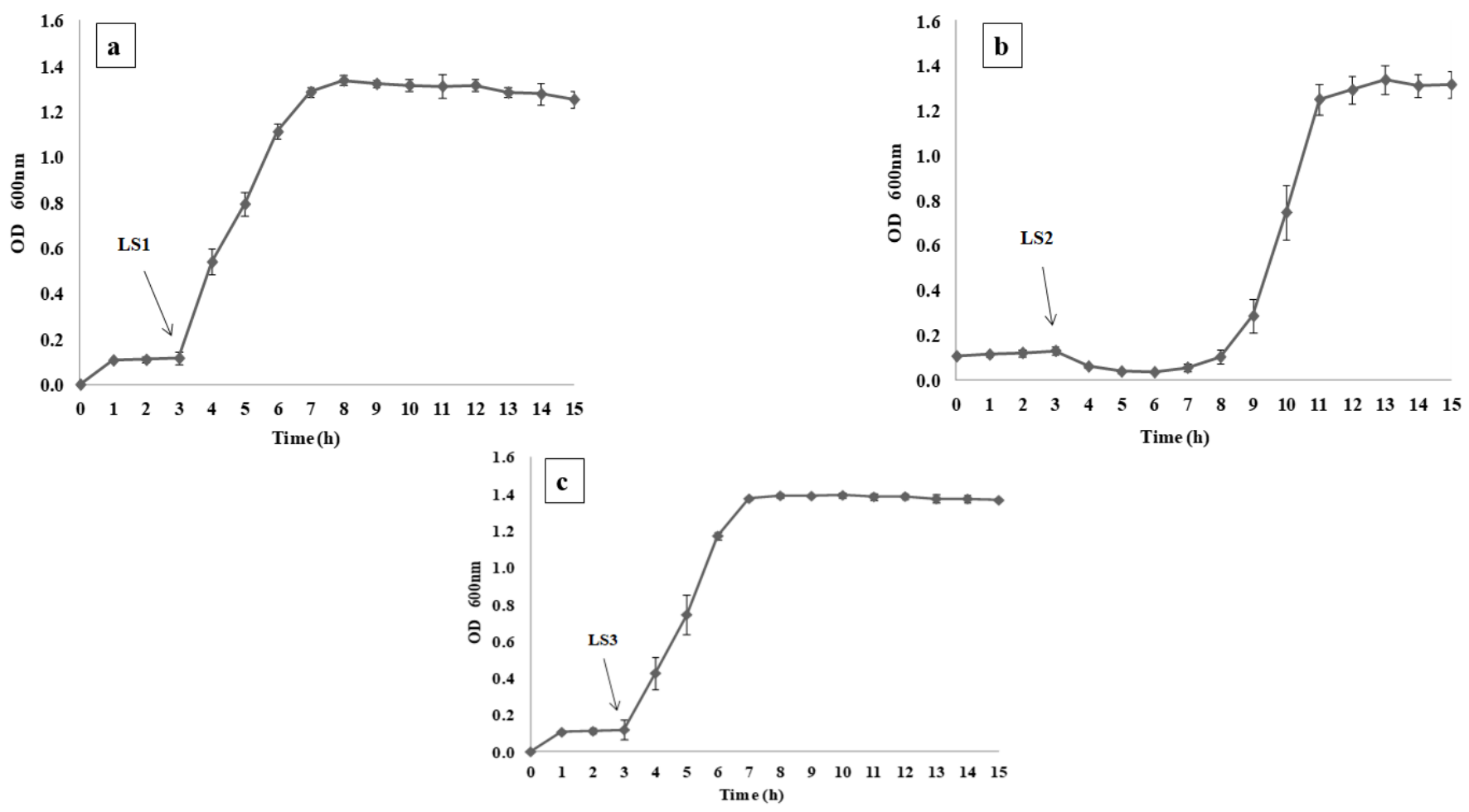

Source: Authors.

\subsection{Adsorption of the anti-Listeria substances present in the CFS of LS2 to L. monocytogenes}

The highest adsorption (100\%) of anti-Listeria substances produced by LS2 against cells of L. monocytogenes 711 (indicator strain) occurred at $30{ }^{\circ} \mathrm{C}$ at $\mathrm{pH}$ values of 6.0, 8.0 and 10.0 , and also at $37{ }^{\circ} \mathrm{C}$ at $\mathrm{pH}$ values of 4.0, 6.0, 8.0 and 10 . Treatment with $10 \mathrm{~g} / \mathrm{L} \mathrm{NaCl}$ and $10 \mathrm{~g} / \mathrm{L}$ Tween 80 resulted in $100 \%$ and $50 \%$ adsorption, respectively (Table 2).

Table 2 - Effect of temperature, $\mathrm{pH}$, and chemicals in adsorption assays of the LS2 cell-free supernatants (CFS) to $L$. monocytogenes.

\begin{tabular}{|c|c|}
\hline Temperature $\left({ }^{\circ} \mathbf{C}\right)$ & Adsorption (\%) ${ }^{\dagger}$ \\
\hline 4 & $50.0^{*}$ \\
\hline 25 & $50.0^{\ddagger}$ \\
\hline 30 & $83.3 *$ \\
\hline 37 & $100.0^{\ddagger}$ \\
\hline \multicolumn{2}{|l|}{ pH } \\
\hline 4.0 & $50.0^{*}$ \\
\hline 6.0 & $100.0^{\ddagger}$ \\
\hline 8.0 & $100.0^{*}$ \\
\hline 10.0 & $100.0^{\ddagger}$ \\
\hline \multicolumn{2}{|l|}{ Chemicals (10 g/L) } \\
\hline Tween 80 & $50.0 *$ \\
\hline $\mathrm{NaCl}$ & $100.0^{\ddagger}$ \\
\hline
\end{tabular}




\subsection{Molecular identification of LAB isolates with anti-Listeria activity}

The nucleotide sequence of a 1465 bp fragment amplified from genomic DNA of LS1, LS2 and LS3 was compared and aligned with the NCBI and RDP databases. This revealed that the 16S rRNA gene nucleotide sequences have a clear similarity of 97\% with Weissella cibaria for LS1, and of 99\% with L. lactis for LS2 and LS3 (Fig. 4). The sequences were assigned GenBank accession numbers: LS1 (BankIt1779156 KP213176), LS2 (BankIt1779156 KP213177), and LS3 (BankIt1779156 KP213178).

Figure 4 - Molecular phylogenetic analysis by the maximum likelihood method.

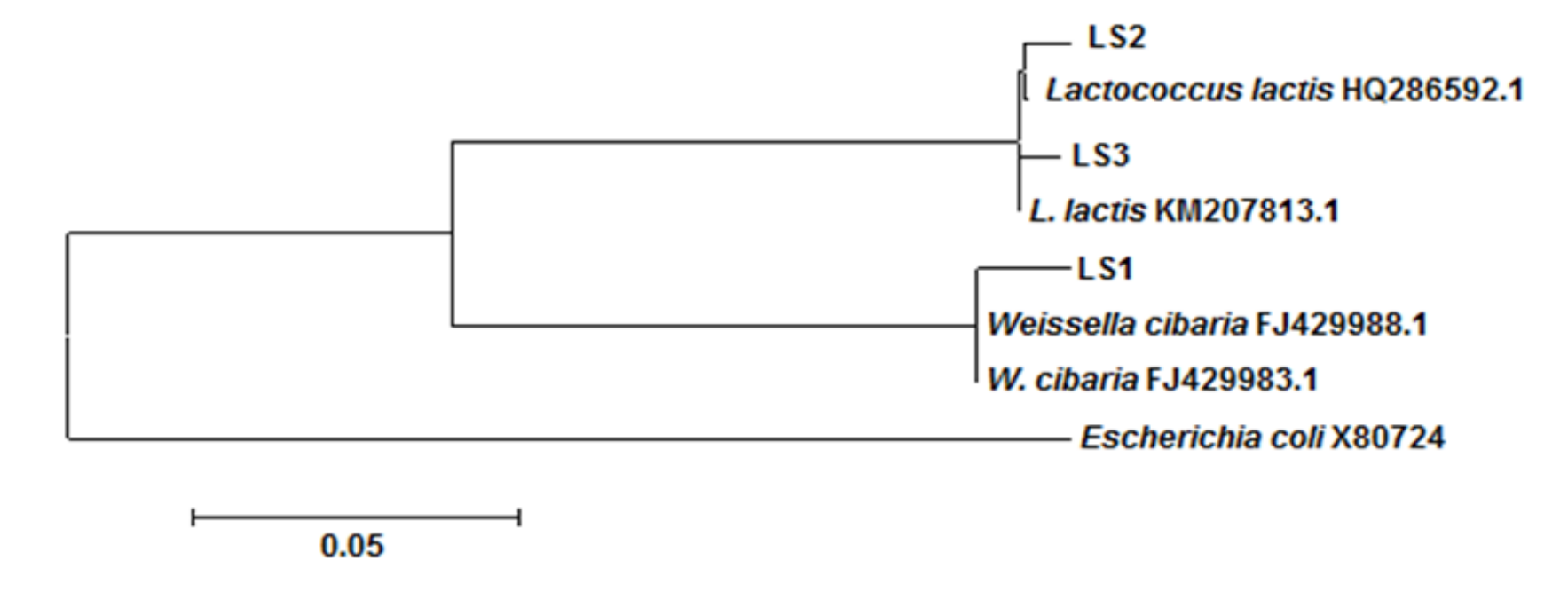

Source: Authors.

\section{Discussion}

LAB with antimicrobial and anti-Listeria activity have been isolated from the milk of goats, camels, and cows (Fatma and Benmechernene, 2013; Perin and Nero, 2014; Sip et al., 2012). Considering the ubiquitous nature of Listeria species and their capacity to form biofilms on the surfaces of dairy products undergoing processing, the synthesis of compounds with activity against this bacterium is an important area of research, as is identifying strategies that promote LAB survival in food matrices such as mil (Guerrieri et al., 2009).

Some studies report CFS from LAB as being frequently active against L. monocytogenes (Hartmann; Wilke and Erdman, 2011; Pinto; Fernandes and Pinto, 2009), reinforcing the hypothesis of environmental competition between these microorganisms. As for the protein nature of CFS of lactic bacteria, similar results to the presented here were registered for other bacteriocinigenic LAB (Todorov, 2010).

It was reported that CFS from L. lactis subsp. lactis 521 and Lactococcus lactis subsp. lactis 2 MT had stable antibacterial activity in a pH range of 2.0 to 8.0 and of pH 2.0 to 10.0, respectively (Albano et al., 2007; Sip et al., 2012; Kaktcham et al., 2019). It is noticeable that many dairy products have $\mathrm{pH}$ values near neutral, such as some cheese varieties, and therefore can be targets to receive antibacterial substances without large $\mathrm{pH}$ stability.

Anti-Listeria bacteriocin with stability at high temperatures was reported (Wang et al., 2014); even after heating the isolated supernatants at $121^{\circ} \mathrm{C}$ for $15 \mathrm{~min}$, they were still able to inhibit L. monocytogenes. Variations in the thermostability of anti-Listeria bacteriocins produced by LAB including L. lactis are common, with reports of activity after treatment at $60{ }^{\circ} \mathrm{C} / 30$ $\min , 100{ }^{\circ} \mathrm{C} / 30 \mathrm{~min}$ and even at sterilization temperature $\left(121^{\circ} \mathrm{C} / 15 \mathrm{~min}\right.$ ) (Sip et al., 2012). Considering that addition of 
bacteriocinogenic strains has been studied in different food matrices, their potential application in foods processed under mild conditions could counterbalance the temperature effects observed in antibacterial activity of the isolate LS1.

Because Listeria monocytogenes was able to grow after $5 \mathrm{~h}$ of inhibition, the bacteriostatic action and duration of the CFS from LS2 is in agreement with findings from previous studies, which have reported anti-Listeria bacteriocin with the same mode of action and active for $7 \mathrm{~h}$ and $10 \mathrm{~h}$ (Albano et al., 2007; Biscola et al., 2013).

The adsorption of CFS of LS2 to L. monocytogenes was $\mathrm{pH}$ - and temperature-dependent, the highest being $37^{\circ} \mathrm{C}$ and $\mathrm{pH}$ 6.0, 8.0 and 10. Other authors have previously reported this influence, which may be due to specific interactions between bacteriocins and the target cells (Biscola et al., 2013; Pingitore et al., 2012; Yildirim; Avsar and Yildirim, 2002).

W. cibaria and L. lactis were lactic acid bacteria isolated, molecularly identified and characterized with antimicrobial potential. W. cibaria is recognized as bacteriocin producer (Wang et al., 2014; Kariyawasam et al., 2019). In addition, L. lactis is also a traditional starter culture for dairy products and the Weissella genus has been used in the production of new probiotic fermented milks (Viegas et al., 2010; Ortolani et al., 2010).

\section{Conclusion}

The results showed a successful isolation of three bacteriocinogenic strains from raw goat milk with anti-Listeria monocytogenes activity. The L. lactis strain (LS2) in particular, which produced a bacteriostatic CFS of proteinaceous nature, active at low $\mathrm{pH}$ (minimum 4.0) and at temperatures from $4{ }^{\circ} \mathrm{C}$ to $80^{\circ} \mathrm{C}$, could be chosen as an alternative for the control of $L$. monocytogenes in foods. Future studies could be developed focusing on the industrial production of this inhibitory supernatant of L. monocytogenes, thus avoiding possible foodborne diseases.

\section{Acknowledgments}

This work was supported by the Coordination for the Improvement of Higher Education Personnel (CAPES) [grant of the first and third author]. The authors also acknowledge Dr. Maria T. Destro, Dr. Eb Chiarini and Dr. Bernadette D. G. M. Franco (Laboratory of Microbiology, Pharmaceutical Sciences Faculty, University of São Paulo) for various L. monocytogenes strains used as indicators in this study.

\section{References}

Albano, H.; Todorov, S. D.; Reenen, C. A.; Hogg, T.; Dicks, L. M. T. \& Teixeira P. (2007), "Characterization of two bacteriocins produced by Pediococcus acidilactici isolated from "Alheira", a fermented sausage traditionally produced in Portugal", International Journal of Food Microbiology, $116,239-247$.

Bartman, S.; Ghosh, R. \& Mandal, N. C. (2018), "Production optimization of broad spectrum bacteriocin of three strains of Lactococcus lactis isolated from homemade buttermilk", Annals of Agrarian Science, 16, 286-296.

Biscola, V.; Todorov, S. D.; Capuano, V. S. C.; Abriouel, H.; Gálvez, A. \& Franco, B. D. G. M. (2013), "Isolation and characterization of a nisin-like bacteriocin produced by a Lactococcus lactis strain isolated from charqui, a Brazilian fermented, salted and dried meat product”, Meat Science, 93, 607-613.

Bizani, D.; Morrissy, J. A.; Dominguez, A. P. M. \& Brandelli, A. (2008), "Inibition of Listeria monocytogenes in dairy produts using the bacteriocin-like peptide cerein 8A", International Journal of Food Microbiology, 121, 229-233.

Cavicchioli, V. Q.; Dornellas, W. S.; Perin, L. M.; Pieri, F. A.; Franco, B. D. G. M.; Todorov, S. D. \& Nero, L. A. (2015), “Genetic diversity and some aspects of antimicrobial activity of lactic acid bacteria isolated from goat milk", App Biochemistry and Biotechnology, 175, $2806-2822$.

Coelho, M. C.; Silva, C. C. G.; Ribeiro, S. C.; Dapkevicius, M. L. N. E. \& Rosa, H. J. D. (2014), "Control of Listeria monocytogenes in fresh cheese using protective lactic acid bacteria", International Journal of Food Microbiology, 191, 53-59.

Dal Bello, B.; Cocolin, L.; Zeppa, G.; Field, D.; Cotter, P. D. \& Hill, C. (2012), "Technological characterization of bacteriocin producing Lactococcus lactis strains employed to control Listeria monocytogenes in Cottage cheese", International Journal of Food Microbiology, 153, 58-65.

Martinis, E. C. P. \& Franco, B. D. G. M. (1998), “Inhibition of Listeria monocytogenes in pork product by Lactobacillus sakei strain”, International Journal of Food Microbiology, 42, 119-126. 
Fatma, C. H. \& Benmechernene, Z. (2013), "Isolation and identification of Leuconostoc mesenteroides producing bacteriocin isolated from Algerian raw camel milk", Food Control, 26, 117-124.

Furtado, D. N.; Todorov, S. D.; Landgraf, M.; Destro, M. T. \& Franco, B. D. G. M. (2015), “Bacteriocinogenic Lactococcus lactis subsp. lactis DF04Mi isolated from goat milk: Application in the control of Listeria monocytogenes in fresh Minas-type goat cheese", Brazilian Journal Microbiology, 46, 201-206.

Guerrieri, E.; Niederhäusern, S.; Messi, P.; Sabia, C.; Iseppi, R.; Anacarso, I. \& Bondi, M. (2009), "Use of lactic acid bacteria (LAB) biofilms for the control of Listeria monocytogenes in a small-scale model", Food Control, 20, 861-865.

Hartmann, H. A.; Wilke, T. \& Erdman, R. (2011), "Efficacy of bacteriocin-containing cell-free culture supernatants from lactic acid bacteria to control Listeria monocytogenes in food", International Journal of Food Microbiology, 46, 192-199.

Kaktcham, P. M.; Kouam, E. M. F.; Tientcheu, M. L. T.; Temgoua, J. B.; Wacher, C.; Ngoufack, F. Z. \& de Lourdes Pérez-Chabela, M. (2019), "Nisin-producing Lactococcus lactis subsp. lactis 2MT isolated from freshwater Nile tilapia in Cameroon: Bacteriocin screening, characterization, and optimization in a low-cost medium", LWT- Food Science and Technology, 107, 272-279.

Kariyawasam, K. M. G. M. M.; Jeewanthi, R. K. C.; Lee, N. K. \& Paik, H.D. (2019), "Characterization of cottage cheese using Weissella cibaria D30: Physicochemical, antioxidant, and antilisterial properties”, Journal of dairy science, 102, 3887-3893.

Malheiros, P. S.; Cuccovia, I. M. \& Franco, B. D. G. M. (2016), "Inhibition of Listeria monocytogenes in vitro and in goat milk by liposomal nanovesicles containing bacteriocins produced by Lactobacillus sakei subsp. sakei 2a”, Food Control, 63, 158-164.

Moraes, P. M.; Perin, L. M.; Ortolani, M. B. T.; Yamazi, A. K.; Viçosa, G. N. \& Nero, L.A. (2010), "Protocols for the isolation and detection of lactic acid bacteria with bacteriocinogenic potential", Food Science and Technology, 43, 1320-1324.

Oliveira, D. E.; Bacchi, M. M.; Macarenco, R. S. S.; Tagliarini, J. V.; Cordeiro, R. C. \& Bacchi, C. E. (2006), "Human papillomavirus and Epstein-Barr virus infection, p53 protein expression, and cellullar proliferation in laryngeal carcinoma", American Journal of Clinical Pathology, 126, $284-293$.

Ortolani, M. B. T.; Moraes, P. M.; Perin, L. M.; Viçosa, G. N.; Carvalho, K. G.; Silva Júnior, A. \& Nero, L. A. (2010), "Molecular identification of naturally occurring bacteriocinogenic and bacteriocinogenic-like lactic acid bacteria in raw milk and soft cheese", Journal of Dairy Science, 93, $2880-2886$.

Perin, L. M. \& Nero, L. A. (2014), “Antagonistic lactic acid bacteria isolated from goat milk and identification of a novel nisin variant Lactococcus lactis", BCM Microbiology, 14, 1-9.

Pingitore, E. V.; Todorov, S. D.; Sesma, F. \& Franco, B. D. G. M. (2012), “Application of bacteriocinogenic Enterococcus mundtii CRL35 and Enterococcus faecium ST88Ch in the control of Listeria monocytogenes in fresh Minas cheese", Food Microbiology, 32, 38-47.

Pinto, A. L.; Fernandes, M.; Pinto, C.; Albano, H.; Castilho, F.; Teixeira, P. \& Gibbs, P. A. (2009), "Characterization of anti-Listeria bacteriocins isolated from shellfish: Potential antimicrobials to control non-fermented sea food”, International Journal of Food Microbiology, $129,50-58$.

Queiroga, C. R. E.; Costa, R. G.; Madruga, M. S.; Medeiros, A. N.; Santos, G.; Magnani, M. \& Souza, E.L. (2016), "Influence of lactation stage and some flock management practices on sensory characteristics of goat milk from Brazilian Saanen breed", Animal Science Journal, 87, 600-606.

Rosa, C. M.; Franco, B. D. G. M.; Montville, T. J. \& Chikindas, M.L. (2002), "Purification and mechanistic action of a bacteriocin produced by a Brazilian sausage isolated Lactobacillus sake 2a", Journal of Food Safety, 22, 39-54.

Sip, A.; Ckowicz, M. W.; Olejnik-Schmidt, A. \& Grajek, W. (2012), “Anti-Listeria activity of lactic acid bacteria isolated from golka, a regional cheese produced in Poland", Food Control, 26, 117-124.

Swaminathan, B. \& Gerner-Smidt, P. (2007), “The epidemiology of human listeriosis”, Microbes Infection, 9, $1236-1243$.

Tamura, K.; Stecher, G.; Peterson, D.; Filipski, A. \& Kumar, S. (2013), "MEGA6: Molecular Evolutionary Genetics Analysis version 6.0”, Molecular Biology and Evolution, 30, 2725-2729.

Todorov, S. D. \& Dicks, L. M. T. (2006), "Screening for bacteriocin-producing lactic acid bacteria from boza, a traditional cereal beverage from Bulgaria, Comparison of the bacteriocins", Process Biochemistry, 41, 11-19.

Todorov, S. D. (2010), "Diversity of bacteriocinogenic lactic acid bacteria isolated from boza, a cereal-based fermented beverage from Bulgaria", Food Control, $21,1011-1021$

Turner, S.; Pryer, K. M.; Miao, V. P. W. \& Palmer, J. D. (1999), "Investigating deep phylogenetic relationships among cyanobacteria and plastids by small subunit rRNA sequence analysis", Journal of Eukaryotic Microbiology, 46, 327-338.

Umu, Ö. C.; Bäuerl, C.; Oostindjer, M.; Pope, P. B.; Hernández, P. E.; Pérez-Martínez, G. \& Diep, D.B. (2016), “The potential of class II bacteriocins to modify gut microbiota to improve host health", Plos one, 11, 1-22.

Viegas, R. P.; Souza, M. R.; Figueiredo, T. C.; Resende, M. F. S.; Penna, C. F. A. M. \& Cerqueira, M. M. O. P. (2010), "Quality of fermented milks produced by the use of lactic acid bacteria isolated from coalho cheese", Arquivo Brasileiro de

Medicina Veterinária e Zootecnia, 62, 460-467.

Wang, G.; Ning, J.; Zhao, J.; Tian, F.; Zhao, J.; Chen, Y.; Zhang, H.; Chen, W.; Chen, W. \& Hang, F. (2014), "Partial characterisation of an anti-listeria substance produced by Pediococcus acidilactici P9", International Dairy Journal, 34, 275-279.

Yildirim, Z.; Avşar, Y. K. \& Yildirim, M. (2002), "Factors affecting the adsorption of buchnericin LB, a bacteriocin produced by Lactobacillus buchneri", Microbiological Research, 157, 103-107. 